\section{Turing at 100}

\section{This year marks the centenary of the birth of Alan Turing. He deserves your attention.}

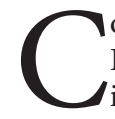
ome the summer, many minds will turn to sport as the London Olympics kicks off. So it seems apt that, in a special issue this week, Nature invites its readers to embrace and celebrate a superb marathon runner - who also happened to be one of the brightest minds of all time.

Alan Turing, computer pioneer, wartime code-breaker and polymath, was born in London on 23 June 1912. But for injury, he would probably have joined the British Olympic team for the London games of 1948. (His personal best marathon time of 2 hours and 46 minutes was barely 11 minutes behind the gold medallist that year.) Yet, 100 years and one month after his birth, when the Olympics will return to the city, no official celebration of the connection is planned. An opportunity to bring an intellectual giant - and science itself - to the attention of the international public will be missed.

Turing's marathon time gives us an objective quantification of his physical excellence. His scientific genius and legacy, however, are much more difficult to measure - as his biographer, Andrew Hodges, a mathematician at the University of Oxford, UK, points out on page 441. Still, setting aside quarrels over his role in the development of the computer, the scientific world should stand together and relish the wonderful diversity of a universal mind. (See the special section starting on page 455 and www.nature.com/turing for more.)

The scope of Turing's achievements is extraordinary. Mathematicians will honour the man who cracked David Hilbert's Entscheidungsproblem or 'decision problem', and cryptographers and historians will remember him as the man who broke Nazi Germany's Enigma code and helped to shorten the Second World War. Engineers will hail the founder of the digital age and artificial intelligence. Biologists will pay homage to the theoretician of morphogenesis, and physicists will raise a glass to the pioneer of nonlinear dynamics. Philosophers, meanwhile, are likely to continue to frown over his one-liners on the limits of reason and intuition: "If a machine is expected to be infallible, it cannot also be intelligent," he said in a 1947 talk to the London Mathematical Society.

Turing demonstrated a terrific ability to combine first-hand experimentation, keen observation, rigorous theory and practical application. His multidisciplinary approach alone makes him of interest to this jour-
"Turing's mind was truly his own, and this contributed to the tragedy of his life." nal, yet questions still arise on whether the best papers in pure mathematics, computer science and artificial intelligence should be published in Nature. We certainly think so.

So, too, do the researchers invited to decode Turing's legacy in a series of Comment articles, starting on page 459 . They are thoughtprovoking pieces in their own right, but, more importantly, we hope that they will entice readers to seek out Turing's original work (see, for example, B. J. Copeland (ed.) The Essential Turing; Clarendon, 2004). His papers are models of accessibility and clarity, despite their extreme conceptual depth and intellectual rigour. Even his throwaway comments - about symmetry in physics versus biology, randomness in intelligence, learning in unorganized machines, or emotions in extrasensory perception, for example - are gems.

Turing's mind was truly his own, and this contributed to the tragedy of his life. Turing was persecuted by the British authorities for his homosexuality, and used cyanide to take his own life, aged 41.

That 2012 will see numerous events commemorating Turing worldwide (see, for example, www.turingcentenary.eu) is almost entirely down to volunteers, who have received little or no official help. This is in stark contrast to the World Year of Physics in 2005, when the German state helped to promote the centenary of Albert Einstein's 'miracle year', in which he published his four groundbreaking papers.

What could 2012, the Alan Turing year, be named? Nature suggests 'The Year of Intelligence. Of the finest types of intelligence - human, artificial and military - Turing is perhaps the only person to have made a world-changing contribution to all three. Use this special issue, and the rest of 2012, to discover and make up your own mind about this extraordinary man.

\section{Over the line}

\section{Dishonesty, however tempting, is the wrong way to tackle climate sceptics.}

\section{I} n a much-quoted Editorial in March 2010 (Nature 464, 141; 2010), this publication urged researchers to acknowledge that they are involved in a street fight over the communication of climate science. So would it now be hypocritical to condemn Peter Gleick for fighting dirty? Gleick, a hydroclimatologist and president of the Pacific Institute for Studies in Development, Environment and Security in Oakland, California, admitted in a statement on news website The Huffington Post on 20 February that he had duped the Heartland Institute, a right-wing think tank based in Chicago, Illinois, into handing over documents that detailed its financial support for climate sceptics. Gleick had passed these documents on to the website DeSmogBlog.com, which made them public on 14 February.

Gleick's deception - using an e-mail address set up in someone else's name to request the documents from Heartland - is certainly in line with some of the tactics used to undermine climate science. When in November 2009 a hacker distributed thousands of e-mails stolen from climate researchers at the University of East Anglia in Norwich, UK, Heartland was prominent among those who criticized not the hacker, but the scientists who wrote the messages. However,

Gleick, as he has admitted, crossed an important line when he acted in such a duplicitous way. It was a foolish action for a scientist, especially one who regularly engages with the public and critics. Society rightly looks to scientists for fairness and impartiality. Dishonesty, whatever its form and motivation, is a stain on the individual and the profession. Gleick does deserve credit for coming clean - but, it must be said, he did so only after he was publicly accused on the Internet of being involved.

The original accusation, incidentally, was more serious: that Gleick had deliberately forged a Heartland Institute memo that brought together, with suspicious convenience, the most incriminating sections of the other climate documents, which seem to have been presented to the Heartland board meeting in January. He denies doing so, and says that he received the memo, in which he is named and which Heartland says has been faked, separately from an anonymous source. The e-mail chicanery, he says, was an attempt to check whether it was genuine.

In his statement on Monday, Gleick said: "My judgment was blinded by my frustration with the ongoing efforts - often anonymous, wellfunded, and coordinated - to attack climate science and scientists and prevent this debate, and by the lack of transparency of the organizations involved. Nevertheless I deeply regret my own actions in this case."

On 24 January, Gleick had published another article in The Huffington Post, entitled 'Climate Change: Sifting

$\rightarrow$ NATURE,COM To comment online, click on Editorials at: go.nature.com/xhunqv Truth From Lies in a Complex World'. As he now knows, the best way for scientists to help people find this truth is through open and honest debate. 